\title{
NA RELEITURA DE $O$ BURGUÊS FIDALGO, UM PROJETO EM PROL DA FORMAÇÃO DOS NEOLEITORES
}

\author{
Alessandra Oliveira dos Santos Beltramim* \\ Mírian Hisae Yaegashi Zappone ${ }^{* *}$
}

\begin{abstract}
Resumo: Esse artigo apresenta uma leitura do perfil de leitor idealizado pela adaptação da peça $O$ burguês fidalgo, de Molière, por Walcyr Carrasco (2003). Como parte da Coleção Palavra da Gente $E J A$, a obra passa por um explícito projeto de reendereçamento ao público da modalidade educacional de jovens e adultos. Considerando os pressupostos da estética da recepção, que atribuem um papel significativo para o leitor na configuração dos textos, recorremos ao significado substantivo e adjetivo dos gêneros literários (ROSENFELD, 1985) para analisar os traços estilísticos do drama que prevalecem nessa peça. Os expedientes lançados pelo dramaturgo, nesse processo, evidenciam uma tentativa de manipulação dos sentidos possíveis para o texto, assumindo alguns aspectos que seriam mais característicos do gênero épico.
\end{abstract}

Palavras-chave: O burguês fidalgo. Drama. Formação de leitores.

\begin{abstract}
This paper presents the profile of the reader idealized by Walcyr Carrasco in adaptation of the Molière's O burguês fidalgo (2003). As part of the Coleção Palavra da gente - EJA, the piece goes through an explicit project of re-awarding to the public made up of students of the educational modality of youth and adults. Considering the presuppositions of the reception aesthetics, which assign a significant role to the reader in the configuration of texts, we seek to investigate the substantive and adjective meaning of the literary genres proposed by Rosenfeld (1985) to analyze the stylistic traits of the drama that prevail in this text. The files released by the playwright, in this process of re-rendering, evidence an attempt to manipulate the possible meanings for the text, assuming some aspects that would be more characteristic of the epic genre.
\end{abstract}

Keywords: O burguês fidalgo. Drama. Readers development.

\section{Introdução}

Quem, em sua sã consciência, seria capaz de afirmar que temas como o desejo de ascender socialmente a qualquer custo ou a preocupação demasiada com o status social estariam hoje ultrapassados? Quem negaria a existência de indivíduos deslumbrados pelo poder do dinheiro a tal ponto de acreditarem que tudo é passível de ser comprado, inclusive o amor e a amizade? Tratando essencialmente desses temas, a peça teatral $O$ burguês fidalgo, de Molière, originalmente contextualizada no século XVII, na sociedade parisiense do tempo do rei Louis XIV, onde foi escrita e encenada, "ultrapassou as fronteiras de seu país de origem e a época de sua criação", tornando-se "patrimônio da humanidade, lida, encenada e aplaudida em todo o mundo" (LAJOLO, 2003, p.4).

Tal sucesso pode se justificar pela universalidade da obra, cuja história poderia se passar em qualquer tempo e em qualquer lugar, o que facilitou a sua retomada em diferentes épocas e em diversas partes do mundo, readaptando-se a diferentes contextos, atendendo, assim, a públicos heterogêneos, de modo sempre atual. Referendando o valor não só dessa peça, mas de toda a produção cômica de Molière, Suani Trindade Corrêa (2011) defende que "mais do que qualquer obra, a de Molière critica os excessos

*Doutoranda em Letras (UEM - Universidade Estadual de Maringá) - ale-higobeltramim @ hotmail.com ** Doutora em Letras / Professora Adjunta do Departamento de Letras (UEM - Universidade Estadual de Maringá) - mirianzappone@gmail.com 
humanos pintando-os de maneira extremamente viva. Daí o seu valor permanente: é uma obra na qual cada época, cada indivíduo mesmo, poderia encontrar do que corrigir seus vícios" (CORRÊA, 2011, p.45).

Walcyr Carrasco, por sua vez, acreditando que "um texto teatral se torna vivo através dos séculos pela capacidade que tem de falar com a gente até os dias de hoje" (CARRASCO, 2003, p.7), propõe, também, uma adaptação da peça ao seu público brasileiro contemporâneo do século XXI. O autor, além de roteirista de peças teatrais e de várias novelas da Rede Globo, é cronista da Veja São Paulo e é, também, muito conhecido pelo sucesso conquistado como autor de literatura infantojuvenil. É um autor bastante versátil e atuante, produzindo textos originais e adaptados, de peças teatrais a romances, contos e novelas, abrangendo diferentes públicos e abordando temáticas bastante diversificadas. Mas, provavelmente, pela sua linguagem simples e objetiva, o autor - enquanto literato - encontra um público privilegiado entre as crianças, adolescentes e jovens.

No trabalho de adaptação da peça $O$ burguês fidalgo, de Moliére, por sua vez, constata-se, mais uma vez, essa versatilidade do autor, essa capacidade de comunicar, numa linguagem simples e prosaica, com o público de massas, já acostumado aos produtos da indústria cultural, confirmando sua adequação a um público pouco acostumado a leituras de maior densidade psicológica. Apesar de pertencer à coleção Palavra da gente, da Editora Moderna, projeto idealizado para o público da modalidade EJA de ensino - Educação de Jovens e Adultos, percebe-se, na peça, uma apropriação de elementos recorrentes no âmbito da literatura juvenil, aproximando-se, também, do leitor juvenil contemporâneo. Afinal, como sugere Lígia Cademartori, "quando falamos em literatura juvenil, não pensamos propriamente em gênero literário, nem em indivíduo e, muito menos, em um sujeito a que tal literatura se destine. Em geral, a ideia que temos é de um tipo de texto aceito e promovido por determinada instituição" (2009, p.61). Sem dúvida, tal instituição é a escola, ambiente ao qual a obra é destinada uma vez que é inserida em uma coleção que explicita a marca da modalidade educacional para jovens e adultos como público previsto na configuração do acervo específico da coleção. Para Cademartori (2009, p.61),

é a partir da escola que se pensa e conceitua o que seja literatura juvenil, e isso, por si só, revela o caráter instrumental que lhe é atribuído. A partir da escola como destino e marco, costuma-se rotular de juvenil a literatura endereçada a alunos das séries finais do ensino fundamental e àqueles que frequentam o ensino médio.

Certamente, a experiência de Walcyr Carrasco como escritor de literatura infantojuvenil foi determinante para que bem desempenhasse o seu papel no projeto da Coleção Palavra da Gente, reunindo, em seu texto, os elementos que o Ministério da Educação, financiador do projeto, considera pertinentes ao universo dos leitores estudantes da modalidade EJA de ensino.

Tal aproximação pode ser justificada pelo fato de ambos os públicos infantojuvenil e estudantes da modalidade EJA - pertencerem a uma categoria social de leitores em processo de formação, leitores para os quais o mercado editorial, muitas vezes, com financiamento público, tem se voltado nas últimas décadas, sendo o governo federal o maior comprador de livros do país. O público da EJA também tem sido associado à categoria social dos neoleitores, público para o qual têm sido destinados alguns projetos de formação do leitor, com o objetivo de formar leitores e aumentar os 
índices de leitura no país, ainda deficitários e distantes do ideal almejado, principalmente no que se refere à leitura literária.

O que interessa para esse estudo nessa versão da peça $O$ burguês fidalgo, portanto, muito além da sua temática e das questões ideológicas nela representadas, é exatamente o processo de reendereçamento capaz de transformar um clássico em um objeto de leitura para leitores em processo de formação, sejam eles o público da modalidade de Jovens e adultos ou ainda o público juvenil. Por isso, nos perguntamos: Quais seriam as características desse texto clássico que se faz novo a cada vez que é retomado e readaptado? Qual é o perfil do leitor / receptor implícito previsto na obra? Em quais recursos e expedientes Walcyr Carrasco teria se amparado para atender ao propósito da coleção proposta pelo governo federal? Quais são os traços estilísticos do Drama - e por que não da Lírica ou da Épica - incorporados à peça? Que estratégias permitem a recepção do clássico por novos leitores, pouco experimentados no universo das Letras? Quais seriam as características inerentes aos produtos da Indústria Cultural identificáveis nessa peça?

Os questionamentos, realmente, se multiplicam e, para melhor discuti-los, primeiramente, fundamentamos nossa pesquisa nos princípios da Estética da Recepção (Jauss) e das Teorias do Efeito Estético (Iser), para as quais o papel do leitor adquire elevada importância, no processo de análise de uma obra literária. Na sequência, apresentamos alguns aspectos da discussão teórica que envolve a definição dos gêneros, procurando abordar o significado substantivo e adjetivo dos mesmos, na perspectiva de Rosenfeld (1985) e, num terceiro momento, finalmente, apresentamos a coleção na qual a peça está inserida e submetemos o texto a uma análise acerca dos principais traços estilísticos que o compõem, procurando identificar possíveis interferências do leitor implícito, idealizado na configuração da mesma.

\section{Coleção Palavra da gente e os neoleitores: a adaptação da obra a um novo público}

Inscrita na Coleção Palavra da gente, a obra $O$ burguês fidalgo, de Molière, adaptada por Walcyr Carrasco (2003), explicita os neoleitores da modalidade educacional de jovens e adultos como destinatários previstos em sua edição e criação. Embora saibamos que, após publicados, os textos literários podem se prestar a leituras diversas e incontroláveis por quem as produziu, é preciso considerar que os leitores principalmente quando delimitados de forma tão explícita - se constituem parte significativa do processo de construção dos seus sentidos. A partir dos pressupostos da Estética da Recepção e da Teoria do Efeito Estético, trazidas ao Brasil por Luiz Costa Lima, a partir de 1979, as categorias de análise de uma obra são ampliadas com a possibilidade e pertinência de se considerar, também, o foco no leitor que, por sua vez, pode ser entendido como o leitor real, aquele que lê a obra, mas também como aquele leitor implícito, previsto pelo texto em seu processo de criação e pertencente à estrutura do próprio texto. Em síntese, a partir do conhecimento dos estudos de Iser e de Jauss, só se pode falar em obra literária quando o pensamento criativo se realiza num texto e este encontra um leitor.

Para Jauss, o leitor, que lê e interpreta a obra de modo único e específico em cada tempo e contexto histórico, é aquele por meio de quem a obra se atualiza. Para Iser, a ênfase é colocada no efeito que a obra provoca no leitor, colocando em evidência a interação entre texto e leitor, no ato da leitura. Segundo Wolfgang Iser (1996, p.50), 
a obra literária tem dois polos que podem ser chamados polos artístico e estético. O polo artístico designa o texto criado pelo autor e o estético a concretização produzida pelo leitor. Segue dessa polaridade que a obra literária não se identifica nem com o texto, nem com sua concretização. Pois a obra é mais do que o texto, é só na concretização que ela se realiza. A concretização por sua vez não é livre das disposições do leitor, mesmo se tais disposições só se atualizam com as condições do texto. A obra literária se realiza, então, na convergência do texto com o leitor; a obra tem forçosamente um caráter virtual, pois não pode ser reduzida nem à realidade do texto, nem às disposições caracterizadas do leitor.

Desse modo, é preciso compreender que o leitor não apenas recebe os sentidos do texto de forma passiva, mas participa do processo de construção de sentidos do mesmo, tanto no próprio processo criativo como também no processo de apropriação daquilo que lê, ao dialogar com a obra, no ato da leitura. Então, a obra literária tem, portanto, um leitor implícito prefigurado em sua estrutura, uma criação ficcional prevista pelo texto e um leitor explícito, o sujeito que efetivará a leitura de fato, seguindo os vazios do texto, conforme as estruturas textuais lhes permitam preencher com seus repertórios particulares de conhecimento do mundo, de leituras anteriores e seus conhecimentos sobre o tema em questão.

Considerando, portanto, o projeto editorial da coleção Palavra da gente, evidencia-se que o contexto escolar é o espaço privilegiado para a circulação da peça, tendo em vista o explícito reendereçamento aos neoleitores da modalidade EJA. É indispensável, portanto, compreender quem seriam esses neoleitores especificados como público potencial previsto para a peça em questão e para toda a coleção.

O glossário virtual do CEALE - Centro de alfabetização, leitura e escrita, um órgão complementar da Faculdade de Educação da UFMG, criado em 1990, com o objetivo de integrar grupos interinstitucionais voltados para a área da alfabetização e do ensino de Português - entende por neoleitores aqueles sujeitos que, inseridos no processo de formação enquanto leitores, seja na fase formal da alfabetização ou de processos informais de aprendizado da leitura, estão expostos a múltiplas formas de leitura em todos os espaços e estímulos sociais. Enfim, neoleitor, segundo o Glossário do CEALE, é aquele que

se inicia na cultura escrita, em qualquer sistema de escrita; o que começa a ler. Sujeito de um processo de formação que não dissocia o aprender a ler do aprender a ser leitor; sujeito complexamente imbricado nos processos de apreensão e atribuição de sentidos a conhecimentos da vida sociocultural em sociedades grafocêntricas. Usado para designar novos leitores jovens, adultos e idosos que trazem para a relação com o texto suas experiências de vida e de mundo, entretecendo sentidos para o que leem, porque potentes e potenciais artífices (PAIVA, 2014, S/P.).

Nessa perspectiva, portanto, evidencia-se que a formação de um leitor não se restringe ao contexto escolar. Esta tarefa formalmente atribuída à escola se dá de modo processual, ao longo da vida, por meio das práticas de letramento escolarizadas, mas também, por meio de outras experiências vivenciadas por todos os sujeitos inseridos em uma sociedade grafocêntrica, mesmo quando ainda não alfabetizados. $\mathrm{O}$ universo 
natural, cultural e social é fonte inesgotável de conhecimentos por meio dos quais a cultura letrada vai sendo incorporada pelos leitores em formação. No entanto, ao aprenderem expressões da linguagem escrita, jovens e adultos abandonam o estigma de analfabetos e "vivem um ritual de passagem da condição de alfabetizandos para o reconhecimento como neoleitores" (CEALE), mesmo que ainda não se reconheçam plenamente como tais. O que importa, nesse caso, é que, como neoleitores, eles se tornam aptos a lerem o mundo, também, por meio de novos códigos, suportes e materialidades dos textos escritos.

No caso da peça aqui analisada, observa-se, portanto, que o processo de reendereçamento do texto clássico a esse novo público traz implicações significativas, também, para os sentidos do texto, dando origem a leituras diversas, configurando novas obras transformadas, reconfiguradas ao serem apropriadas por novos leitores, com diferentes repertórios de leitura e de vivência, em diferentes tempos e contextos, muito distantes do idealizado pelo horizonte de expectativas da obra original. Isso, sem dúvida, repercute na estrutura e configuração do texto adaptado. As traduções, adaptações e recriações literárias constituem, tradicionalmente, na história da leitura, uma legítima via de acesso aos textos clássicos. E, embora ainda se questione a validade desses procedimentos para a configuração do literário, Lígia Cademartori (2009) salienta o potencial desses textos de introduzirem o leitor em formação em um mundo de leituras ampliado, que lhe possibilita entrar em contato com realidades culturais e existenciais por meio de histórias com personagens distantes temporal ou geograficamente, por exemplo, e ainda, se forem preservadas as marcas de identidade da obra original, podem favorecer a inspiração de futuras leituras do texto-fonte.

No Brasil, segundo Girlene Marques Formiga (2009, p.136), as adaptações têm sido veículos de tradição na cultura escolar e, especialmente nesse espaço, os clássicos literários mantêm uma estreita relação com a formação do leitor, favorecendo significativamente a ampliação do repertório e do horizonte de expectativas dos neoleitores. E tal fato não é um fenômeno específico da indústria cultural, uma vez que se faz presente desde o início da formação cultural da sociedade brasileira. Num país onde a educação, por muito tempo, foi privilégio de poucos, a produção artística nacional era bastante restrita e, por isso, as traduções e adaptações de literatura estrangeira foram essenciais para que se iniciasse a formação dos primeiros leitores e autores. O próprio Monteiro Lobato, autor essencial para a formação de uma literatura nacional brasileira, assinou várias obras com a especificação de "tradução e adaptação". Segundo Formiga (2009, p.129), Lobato concebe a tradução como um transplante, no qual o tradutor - ou adaptador - "necessita compreender a fundo a obra e o autor, e reescrevê-la em português como quem ouve uma história e depois conta com suas palavras". Para explicitar a referência, Formiga (2009) discorre sobre a tradicional falta de cuidado de se explicitar as diferenças entre os dois termos - tradução e adaptação, de modo que ambos são usados, muitas vezes, indistintamente. Portanto, para a autora, quando Lobato defende a importância da tradução e do cuidado para que ela tenha qualidade, na verdade, pode estar se referindo, também, ao processo de adaptação, já que o mesmo requer um rigor de qualidade no sentido de "contar com suas palavras" ainda maior que o da tradução.

Para analisar uma obra - e de modo especial, uma adaptação, é importante verificar, por exemplo, algumas questões relacionadas ao tom e ao ponto de vista. Para Arrigucci (1998), tais elementos constituem a base da técnica ficcional, defendendo que a 
escolha da técnica, do ponto de vista, nunca é inocente. Escolher um ângulo de visão ou uma voz narrativa, ou um modo direto ou indireto, tem implicações de outra ordem, ou seja, toda técnica supõe uma visão do mundo, supõe dimensões outras (ARRIGUCCI, 1998, p.20).

Apesar de a afirmação de Arrigucci (1998) aparecer aqui, diretamente relacionada à teoria da narrativa de modo geral, ela pode ser adotada como um interessante ponto de partida para a discussão, também, dos procedimentos estéticos inerentes ao texto dramático.

Não há dúvida de que, em textos épicos [ou narrativos], o comportamento do narrador é de fundamental importância não só para a forma como também para o conteúdo do que um conto ou romance expressam. Mas em relação ao teatro, seria possível identificarmos nos textos procedimentos estéticos que nos permitam identificar algo semelhante ao tom, ao ponto de vista ou à postura de um sujeito que cumpra função equivalente a de um narrador do texto narrativo? Segundo Rosenfeld (1985), "nos gêneros manifestam-se, sem dúvida, tipos diversos de imaginação e de atitudes em face do mundo" (ROSENFELD, 1985, p.17).

Portanto, cada gênero literário tem suas especificidades, em relação a esses aspectos e cada um deles pressupõe, também, alguma atitude em face do mundo, seja esta atitude expressa pelo poeta, pelo narrador ou pelo dramaturgo. Na obra aqui analisada, é possível constatar que, no processo de adaptação, é assumida uma postura narrativa de orientar, de guiar o leitor e, muitas vezes, até mesmo manipular a recepção, através de uma tentativa de controle da construção de sentido do texto por parte do leitor. Tal postura promove uma aproximação da peça teatral ao gênero épico e pode ser explicada em função do contexto de circulação para o qual a presente obra é destinado. Afinal, como vimos, na perspectiva da estética recepcional, além da atitude diante do mundo expressa pelo locutor do texto, na produção de uma obra literária, a obra pressupõe, também, determinadas atitudes do leitor, público para o qual a obra cumpre a sua destinação social. É por isso que o perfil do público leitor / consumidor também interfere na obra, não apenas durante o seu processo de recepção, como também no processo de sua criação. Esta interferência mútua tem se tornado ainda mais explícita no contexto contemporâneo, dominado pela indústria cultural.

Compreender esse processo de interferência mútua entre autor e público, via obra, é de extrema importância, para que se dê visibilidade a uma série de expedientes textuais destinados a guiar / orientar o leitor que aceita assumir o pacto de leitura com o autor através da obra (COMPAGNON, 2001). É esse acordo implícito que permite que o leitor percorra os caminhos do texto, no ato da leitura, preenchendo as lacunas, os vazios encontrados, com sua própria experiência de mundo, de vivência, de leitura.

Se o texto só se completa e se constitui como tal através do ato de leitura, para além da materialidade dos textos, uma análise literária fundamentada na teoria do efeito estético e na estética recepcional deve focalizar, também, o perfil dos leitores presentes na configuração de cada obra. Tal abordagem torna-se ainda mais relevante no contexto contemporâneo dominado pela indústria cultural, em que existe uma explícita tendência à adequação das obras a públicos cada vez mais específicos, no intuito de promover e ampliar o círculo de consumo. No entanto, ao contrário do que muitos apocalípticos da cultura acreditam, tal postura não é uma tendência apenas negativa. Segundo Nelly Novaes Coelho (2010), em seu Panorama Histórico da Literatura Infantil e Juvenil, no limiar do século XXI, não há um ideal absoluto de Literatura Infantil/ Juvenil (nem de nenhuma outra espécie literária). Para a autora, nesse contexto cada vez mais marcado 
pela especialização de públicos cada vez mais específicos para cada tipo de produção, será ideal' aquela que corresponder a uma certa necessidade do tipo de leitor a que ela se destina, em consonância com a época em que ele está vivendo (COELHO, 2010, p.289).

Por essa razão, ao ser inserida na Coleção Palavra da Gente - EJA, a peça de Molière, adaptada por Walcyr Carrasco, nesse processo de endereçamento, adapta-se a um novo público - o estudante da modalidade EJA - e apropria-se, de certa forma, das características do mesmo, deixando implícitos ao longo do texto, alguns espaços a serem preenchidos por esse leitor ideal. Esse leitor, por sua vez, como já discutimos, é um indivíduo que possui uma mínima inserção no universo das letras, mas é um sujeito dotado de uma vasta experiência de vida, acumulada em diferentes esferas da convivência humana.

Na perspectiva de Elisiane Tiepolo (S/D, p.2), o neoleitor é concebido como alguém que possui uma rica experiência de vida, vinculada ao seu trabalho e ao seu cotidiano e que tem contato com todo tipo de material escrito, ainda que não seja usuário desse material. Apesar dele não dominar a linguagem escrita, ele tem um vasto conhecimento acumulado ao longo de suas vivências. Referenciando Moacyr Scliar, Tiepolo (2009) defende, ainda, que a expressão neoleitores recupera a dignidade individual do ser humano ao abrir para ele uma possibilidade de renovação pessoal mediante a leitura. Então, neoleitores significam uma neocultura. Um neopaís, certamente melhor do que aquele que temos. Um país onde a literatura será para todos" (2009, p.2).

Sem dúvida, se o público de neoleitores é caracterizado por algumas especificidades, tais como a falta de familiaridade com materiais escritos, em oposição a um rico conhecimento acumulado em outras esferas da vida, há de se considerar, sim, a necessidade de projetos também específicos em prol da sua formação enquanto leitores literários. Nesse sentido, a preocupação de uma coleção específica para este público, acompanhada de outras políticas, pode se converter em uma alternativa viável, desde que as obras que a constituam não permitam que os critérios didáticos se sobreponham aos valores estéticos na configuração dos textos. Convém lembrar, no entanto, que

\begin{abstract}
nossa história de leitores não começou pelo 'monumento literário'. O primeiro livro que lemos não foi aquele que lemos ontem ou aquele de que ouvimos uma conferência na semana passada. $\mathrm{O}$ respeito pelos passos e pela caminhada do aluno enquanto leitor (que se faz pelas suas leituras como nós nos fazemos leitores por nossas leituras) é essencial. Nesta caminhada é importante considerar que o enredo enreda o leitor (GERALDI, 2008, p.110).
\end{abstract}

Nesse sentido, resgatando a nossa própria história de formação enquanto leitores literários, é possível compreender que os neoleitores também precisam trilhar seus próprios caminhos, traçando seus próprios percursos de leitura, sendo, portanto, válidas as iniciativas voltadas à formação de quem está numa etapa inicial do percurso. Além disso, se entendemos que o leitor experiente se constitui a partir das diversas leituras realizadas ao longo de sua vida, é preciso conceber também que

a qualidade do mergulho de um leitor num texto depende - e muito de seus mergulhos anteriores. A quantidade ainda pode gerar qualidade. Parece-me que deveremos - enquanto professores propiciar um maior número de leituras, ainda que a interlocução que 
nosso aluno faça hoje com o texto esteja aquém daquela que almejaríamos: afinal, quem é o leitor, ele ou nós? (GERALDI, 2008, p. 99).

Essa concepção de Geraldi confirma o posicionamento do referencial curricular nacional para a EJA que, por sua vez, recomenda que os estudantes dessa modalidade de ensino tenham acesso a textos pertencentes a diferentes gêneros, de textos verbais aos não-verbais e destaca dentre esta gama de modalidades textuais, o texto literário, como aquele que consegue instaurar uma complexa e fascinante interação com o leitor (BRASIL, 2002).

Atendendo a esta proposta, a coleção Palavra da gente- EJA reúne seis volumes (reportagem, crônica e conto, texto de tradição popular, poesia, peça teatral e relato de viagem) de textos destinados à Educação de Jovens e Adultos. Publicada pelo Programa Nacional da Biblioteca Escolar, com a chancela do FNDE, a coleção foi coordenada por Ana Mariza Filipouski e é fruto de um projeto voltado especificamente ao atendimento desse público adulto em formação, procurando respeitar suas peculiaridades.

Em relação à versão da peça $O$ burguês fidalgo, de Molière, produzida por Walcyr Carrasco (2003), o fato de haver um reendereçamento explícito através de sua inserção nessa Coleção, a preocupação com o público adquire importância ainda maior, uma vez que existe um claro projeto de adaptação da obra ao seu público. Portanto, uma análise desse material pode nos ajudar a conhecer melhor o perfil do leitor que se pretende formar. Resta-nos analisar, portanto, em que medida o perfil desse público está representado na configuração da obra.

Antes disso, porém, para melhor entender este processo e melhor analisar a interferência da postura autoral da peça $O$ burguês fidalgo sobre o seu público e, do mesmo modo, a interferência do público na postura do autor, é preciso explicitar melhor o aspecto distintivo do gênero dramático, gênero primeiro da peça teatral aqui analisada, em relação aos demais.

\section{O gênero dramático e seus traços estilísticos: existe no Drama uma perspectiva autoral?}

Segundo Rosenfeld (1985), “a maneira pela qual é comunicado o mundo imaginário pressupõe certa atitude em face deste mundo ou, contrariamente, a atitude exprime-se em certa maneira de comunicar". Sendo assim, como já explicitamos anteriormente, é possível entender que "nos gêneros manifestam-se, sem dúvida, tipos diversos de imaginação e de atitudes em face do mundo" (ROSENFELD, 1985, p.17).

O posicionamento de Rosenfeld (1985) se justifica pelas diferentes posturas assumidas pelos locutores em cada gênero. Assim, é possível sintetizar que, enquanto no gênero dramático há um predomínio da imitação, a partir da qual as personagens se apresentam e se expressam por si só; no gênero lírico, há um desaparecimento das vozes das personagens, sobressaindo-se exclusivamente o relato do poeta (na voz do eulírico). Já no gênero épico, há uma alternância de vozes entre o próprio poeta que narra (o narrador) e as personagens que se expressam por si mesmas através do diálogo. Tal diferenciação refere-se apenas ao aspecto substantivo dos gêneros, uma vez que, na acepção adjetiva dos mesmos, é possível encontrar outras especificidades que acabam por permitir o entrelaçamento de características de gêneros distintos em um mesmo 
texto, havendo a possibilidade de encontrarmos um poema dramático ou um romance lírico, por exemplo.

Antes de passarmos à apresentação do significado adjetivo dos gêneros, cumpre-nos salientar, porém, que tal organização sistemática dos mesmos se dá apenas no plano formal, de maneira bastante artificial, como ocorre com toda e qualquer conceituação científica, conforme adverte o próprio Rosenfeld:

Evidentemente ela é, até certo ponto artificial [...]. Estabelece um esquema a que a própria realidade literária multiforme, na sua grande variedade histórica, nem sempre corresponde. Tampouco ela deve ser entendida como um sistema de normas a que os autores teriam de ajustar a sua atividade a fim de produzirem obras líricas puras, obras épicas puras ou obras dramáticas puras. A pureza em matéria de literatura não é necessariamente um valor positivo. Ademais, não existe pureza de gêneros em sentido absoluto (ROSENFELD, 1985, p.16).

E, segundo Flory (2010, p.3), é exatamente ao recusar classificações taxativas e eternas que a produção literária "abre espaço para a discussão e a interpretação de obras de arte singulares em determinado contexto" que, por sua vez, "vê novas formas romperem com classificações estéreis e "bem acabadas"”. O autor defende que

os gêneros são construções sociais e históricas e como tais devem ser considerados, e não como formas fixas ou formas prontas. Elas mudam de acordo com novas configurações político-sociais, expressando questões decisivas para um determinado contexto, promovendo novas perspectivas artísticas e interpretativas (FLORY, 2010, p.3).

Portanto, é preciso reconhecer que as delimitações dos gêneros aqui propostas só se justificam para efeitos didáticos, já que, na prática, os textos se configuram como multiformes, não correspondendo na íntegra ao que categorizam as teorias dos gêneros. São os próprios estudiosos dessas categorias que reconhecem a artificialidade de suas teorias.

Tendo, enfim, explicitado a artificialidade e o aspecto abrangente da teoria proposta, é possível sistematizar, de forma sintética e generalista, o significado substantivo dos gêneros da seguinte forma: A Lírica equivaleria a um poema de extensão menor, na medida em que nele não se cristalizem personagens nítidos e em que, ao contrário, uma voz central - quase sempre um EU - nele exprima seu próprio estado de alma. A Épica, por sua vez, abrangeria toda obra - poema ou não - de extensão maior, em que um narrador apresentar personagens envolvidos em situações e eventos e, por fim, a Dramática corresponderia a toda obra dialogada em que atuem os próprios personagens sem serem, em geral, apresentados, por um narrador (ROSENFELD, 1985, p.17).

Esta concepção geral do significado substantivo do gênero, no entanto, não é suficiente para que tenhamos uma compreensão mais clara das especificidades que cada postura autoral pode incorporar. Afinal, é na concepção adjetiva dos gêneros que são definidos os traços estilísticos de que uma obra pode ser imbuída em maior ou menor grau, independente de qual seja o seu gênero (no sentido primeiro do termo substantivo). Nessa perspectiva, as possibilidades de expressão épica, lírica ou 
dramática se ampliam, trazendo conotações aplicáveis para diferentes contextos da vida humana.

\begin{abstract}
Neste sentido amplo esses termos da teoria literária [épico, lírico, dramático] podem tornar-se nomes para possibilidades fundamentais da existência humana; nomes que caracterizam atitudes marcantes em face do mundo e da vida. Há uma maneira dramática de ver o mundo como que dividido por antagonismos irreconciliáveis; há um modo épico de contemplá-lo serenamente na sua vastidão imensa e múltipla; pode-se vivê-lo liricamente, integrado no ritmo universal e na sua atmosfera impalpável das estações (ROSENFIELD, 1985, p.19)
\end{abstract}

Em sentido amplo, então, é possível afirmar que o gênero épico promove uma emancipação em relação aos estados de alma do poeta (narrador), havendo uma postura mais distanciada do locutor diante dos fatos narrados e, portanto, é mais objetivo que o lírico, por atribuir vozes a outros seres, participando de suas vidas e de seus destinos em maior ou menor grau, pelo seu ato de narrar. No épico, predomina uma função mais comunicativa que expressiva da linguagem, atribuindo ao autor um fôlego maior para abordar no conteúdo um mundo mais amplo, um assunto mais vasto. Há ainda uma contextualização dos fatos num tempo anterior, pertencente ao passado.

A Lírica, por sua vez, é caracterizada pela forte expressão das emoções e disposições psíquicas, dos estados de alma de um eu. Nas palavras de Rosenfeld, "a Lírica tende a ser a plasmação imediata das vivências intensas de um Eu no encontro com o mundo, sem que se interponham eventos distendidos no tempo" (1985, p.22). Pela expressão imediata dos sentimentos representados, justifica-se a brevidade do texto, que se contrapõe à intensidade expressiva nele revelada. Por mais que um poema lírico possa evocar personagens ou elementos do mundo, tais menções só se justificam para exprimir a tristeza, a solidão, a alegria do eu-lírico, de modo que não há distanciamento entre sujeito e objeto. Essa ausência de distância é reiterada pela predominância de tempos verbais no presente, valorizando seu aspecto conotativo, através da exploração do imediatismo, do ritmo e da musicalidade das palavras e dos versos. A Lírica manifesta uma voz do presente que se prolonga no tempo, conotando um presente eterno.

Já o gênero dramático, alvo de nosso interesse aqui, apresenta como um dos principais traços estilísticos o desaparecimento da oposição sujeito - objeto, mas, diferentemente do que ocorre na Lírica, é o mundo que adquire maior autonomia, representando-se emancipado em relação ao narrador e livre de qualquer subjetivação. Para Rosenfeld, enquanto no gênero lírico "o sujeito é tudo, no dramático, o objeto é tudo, a ponto de desaparecer no teatro, por completo, qualquer mediador, mesmo o narrativo que, na Épica, apresenta e conta o mundo acontecido" (ROSENFELD, 1985, p.28). Esta suposta objetividade do drama, sugerida por Rosenfeld, parte do princípio de que em uma peça teatral, não encontramos a voz de um narrador que manipula a história ao alinhar os fatos à sua maneira, nem a expressão subjetiva de um eu-lírico que dá vazão à sua subjetividade.

No gênero dramático, ao atribuir voz a diferentes personagens que se expressam, revelando suas subjetividades, temos uma representação do mundo numa pluralidade de vozes, como se o mesmo estivesse autônomo, absoluto, completamente livre das intenções de um narrador ou de qualquer sujeito. As cenas se desenrolam diante de nós e é como se ao espectador fosse dada plena liberdade para fazer seus próprios julgamentos e posicionamentos frente ao que vê. As cenas se desenvolvem 
diante de nossos olhos como se fossem a própria representação da realidade. Tal representação, porém, embora camufle o trabalho de construção do narrador / dramaturgo, não é completamente isenta de subjetividade, de manipulação.

Portanto, no drama, apesar da frequente ausência de um narrador explícito, estudiosos da literatura dramática já concebem que, embora de forma mais tênue que num romance, por exemplo, nas peças teatrais contemporâneas, também é possível encontrar um olhar perspectivado que se manifesta, por exemplo, na disposição dos atos, na expressão das falas das personagens, na sonoplastia, na iluminação, na organização da peça como um todo. Quase sempre é possível encontrar nas minúcias, o posicionamento autoral de alguém que seleciona as cenas, os figurinos, os cenários e, com isso, manipula, em certa medida, a forma como a arte será recebida. E, mais ainda, quando temos acesso apenas à materialidade textual de uma peça, qualquer leitura que se queira séria, não poderá prescindir da consideração de sua dimensão cênica. Sendo assim, portanto, sempre haverá traços, sinais, tentativas de orientação cênica da peça por seu criador, explicitando-se, mesmo via texto, a representação de um posicionamento, de uma visão de mundo.

É sob esta perspectiva que analisamos a peça $O$ burguês fidalgo, na versão criada por Walcyr Carrasco.

\section{A perspectiva autoral no gênero dramático: na releitura da peça $O$ burguês fidalgo, um projeto em prol da formação do leitor}

No plano do enredo, O burguês fidalgo, em síntese, trata da história de um rico comerciante que queria ascender socialmente a qualquer custo, sendo, para tanto, capaz de recorrer a todos os artifícios possíveis para conquistar um lugar junto à nobreza. Para adquirir o tão sonhado status de nobre, o burguês contrata mestres de música, dança, esgrima e filosofia para fazer dele um homem mais culto, digno de ser aceito como um fidalgo. O burguês paga muito bem a todos esses profissionais, mas é exposto ao ridículo, porque nem todo o seu dinheiro pode camuflar a sua ignorância frente às produções culturais e intelectuais destinadas a um público mais requintado, como é o caso da nobreza.

Vendo os interesses do bondoso, mas ingênuo burguês, um conde aproveita-se da situação para lhe extorquir dinheiro em troca de falsas esperanças de apresentá-lo à corte e ajudá-lo na conquista amorosa de uma fina marquesa, quando, na verdade, o conde usa o dinheiro do comerciante para comprar presentes para a marquesa em seu próprio nome, omitindo que era o burguês o financiador dos jantares e presentes. Sendo facilmente ludibriado por todos e até mesmo pela própria mulher, ao final da peça, o burguês aceita aprovar o casamento da filha com certo fidalgo turco, sem saber que o tal pretendente é, na verdade, o pobre e já conhecido admirador da filha.

Com uma história muito simples, o autor consegue, a partir do exagero e da potencialização da ignorância do burguês, um efeito de elevado grau humorístico. $O$ grau de comicidade aumenta à medida que o protagonista, à semelhança do que ocorre em $O$ avarento e outras comédias de Molière, desconhece o quão ridículo é o seu esforço pelo enobrecimento a qualquer custo, para tornar-se reconhecido como "um homem de qualidade", como aqueles a quem ele admira por frequentarem a corte do rei.

Segundo Propp (1992 apud CORRÊA, 2011, p.44), ao estudar a comicidade e o riso, "o riso que zomba provém sempre do desmascaramento da vida interior e espiritual do homem. Para ele, muitas vezes esses defeitos necessitam de desmascaramento", tal 
como ocorre em Harpagon, em $O$ avarento, que não tem consciência do ridículo a que se expõe, ao ficar tão obcecado pela ânsia de acumular e não gastar seu dinheiro, a ponto de não perceber a própria avareza. Na releitura de Carrasco (2003), porém, há apenas um desmascaramento da hipocrisia e ele só funciona para o público que, ao assistir à peça, toma consciência do quão ridícula e absurda é essa pretensão pelo enobrecimento a qualquer custo. Isso, porque, o protagonista termina a última cena como o mesmo fantoche do início da peça, submetendo-se, por exemplo, às artimanhas do pretendente pobre de sua filha, que se vale da cumplicidade da esposa, da filha, dos amigos e criados do protagonista, para lográ-lo e casar-se com a moça, usando um disfarce de fidalgo turco.

À semelhança de outras personagens das peças de Molière, o burguês é convertido em uma verdadeira marionete nas hábeis palavras de seu criador, representando, de forma caricaturesca, um homem real, que, após ter conquistado a posse material, a partir de seu trabalho no comércio, não desfrutava ainda do conhecimento e influência da elite política e cultural, nem os privilégios políticos diante das autoridades.

O caráter caricaturesco se revela, também, na repetição de situações cômicas, reiteradas em demasia. "O efeito cômico é muitas vezes transmitido, quase que de maneira mecânica, pela repetição de incidentes convencionais à comédia" (ALENCAR, 2014, p.5). Isso fica evidente também na releitura de Carrasco, através da preocupação constante e previsível do Senhor Jourdain em saber se cada forma de expressão artística e cultural - música, dança, filosofia, arte de esgrima, alfaiataria - fazia parte do repertório da corte, dos frequentadores do palácio do rei. Tanto é assim que o protagonista não poupa dinheiro, tempo e disposição para se submeter a tudo o que lhe dizem ser comum entre os fidalgos. Ser coisa de gente elegante era argumento definitivo para convencê-lo a oferecer banquetes em sua casa, a investir em dança, em música, em traje florido de seda. E devido à sua sede insaciável de prestígio, à sua vaidade ingênua, o burguês torna-se presa fácil para manipuladores e exploradores, que zombam da sua ignorância.

É possível observar, no entanto, que, para essa constituição de uma personagem - marionete, é indispensável o trabalho de manipulação de um narrador, de um locutor que apresenta a sua perspectiva dos fatos e, assim, conduz o leitor / espectador, a determinadas interpretações, a determinadas formas de completar os vazios da peça. Percebe-se, portanto, que em $O$ burguês fidalgo, valendo-se das características próprias do gênero, os fatos realmente são apresentados diante do leitor, prescindindo da existência de um narrador.

Como é típico do gênero dramático, o diálogo entre as personagens também é fundamental para que o leitor tome conhecimento da história. Apesar disso, no entanto, é possível contemplar, na peça, uma explícita interferência do narrador que manipula a recepção da peça pelo leitor, ao manifestar-se de maneira intrusa.

Tal intromissão do narrador, ora camuflada por meio da fala das personagens, ora explicitada pelo próprio narrador, tornam a peça perspectivada, contrariando um dos aspectos apresentados como característicos do gênero dramático. Assim, o maior grau de objetividade, garantido, por exemplo, na apresentação pessoal de cada personagem aos olhos do público, é anulado nesta peça.

Quando a personagem se apresenta por si só, no palco, é dada ao público a oportunidade de fazer seus próprios julgamentos acerca dela. No caso de $O$ burguês fidalgo, no entanto, observa-se um subterfúgio bastante recorrente em peças teatrais, que é a utilização de outras personagens para anteciparem, ao espectador, a 
apresentação de um aspecto da mesma. Nesta peça, tal expediente é recorrente, uma vez que não apenas o protagonista como também o conde, a marquesa, o próprio Cléonte e o fidalgo turco são antecipadamente apresentados pelas demais personagens.

Dessa forma, antes mesmo da entrada do Senhor Jourdain, no palco, já se instaura um suspense que gera a expectativa do público em relação à personagem protagonista. O senhor Jourdain é dado a conhecer através do depoimento do mestre de dança e do mestre de música a seu respeito.

Enquanto os dois ensaiam os seus discípulos e dançarinos para uma apresentação encomendada pelo burguês, ambos aproveitam para discutir o caráter do burguês, evidenciando a generosidade com que ele paga seus serviços, em contraste com a ignorância com que ele assiste às suas apresentações, sem dar-lhes o devido reconhecimento. Nesse diálogo, nota-se uma perspectiva narrativa sobrepondo-se à suposta objetividade do julgamento do espectador.

Mestre de dança: Temos tido muito o que fazer, nós dois!

Mestre de música: Ainda bem! Encontramos um homem como nos convém! Esse senhor Jourdain nos proporciona um bom dinheiro. Sonha ser nobre elegante! Seria excelente para a sua dança e para a minha música se todo mundo fosse generoso como ele.

Mestre de dança: Nem tanto assim. Eu gostaria que ele entendesse melhor nosso trabalho artístico

Mestre de música: É verdade. Entende pouco. Mas paga bem. E nossa arte está necessitando mais de dinheiro do que de aplausos! (CARRASCO, 2003, p.15)

São, logo de início, disponibilizados ao espectador, dois julgamentos sobre o pretendente a fidalgo: o desapego material explicitado no fato dele pagar tão bem pelo trabalho dos artistas e a farsa que constituirá toda a trama, uma vez que o protagonista se considera bom cantor, bom dançarino, bom conhecedor da filosofia, bom lutador e até descendente de um fidalgo, quando, na verdade, é um simples burguês que enriqueceu pelo comércio e que pouco conhece de música, dança, esgrima e filosofia. Contrastando com esta apresentação irônica do burguês, a pretensão de saber, de conhecer e de parecer elegante que acompanhará nosso protagonista por toda a peça adquire o tom de farsa aos olhos do público, acentuando o seu efeito cômico. Isso fica evidente, por exemplo, quando o burguês finge entender uma fala em latim do mestre da filosofia, mas pede que seu mestre aja como se ele não entendesse e não soubesse nada de arte, de literatura, de latim, de filosofia. A farsa em que se transforma a vida do burguês pretensioso é representativa de um contexto social da época do Rei Luís XIV ${ }^{3}$, na França, mas é tema recorrente na sociedade contemporânea, também, constituindose, por isso, num tema muito atual, capaz de enredar os públicos de hoje.

A apresentação antecipada do mestre de música e de dança é renovada, também, de outro importante aspecto da nossa sociedade: a exploração da ingenuidade e da ignorância alheia, para obtenção de lucros. Tanto é assim que, ao longo de toda a peça, nenhum dos profissionais contratados pelo senhor Jourdain, nem seu suposto amigo conde falido, são capazes de denunciar a situação risível em que ele se encontra. Muito pelo contrário, todos se aproveitam ao máximo para explorar suas fragilidades e

\footnotetext{
${ }^{3}$ O Burguês Fìdalgo (de Molière) evoca a ascensão da burguesia que Louis XIV elevou aos primeiros postos do estado (ALENCAR, 1996, p.4).
} 
para enganá-lo, alimentando sua ilusão de ser reconhecido como nobre, de conseguir casar-se com uma marquesa viúva e de ser aceito no palácio do rei.

São várias as situações em que a figura do burguês, mesmo apresentando-se de forma ridícula, é alvo de crítica elogiosa por parte de seus bajuladores: "O senhor é magnífico" (CARRASCO, 2003, p.26) - diz o mestre de música após uma desastrosa apresentação do burguês na aula de esgrima. "Alguém tão magnífico como Vossa Excelência, com tanta sensibilidade para as coisas belas, deveria oferecer um concerto em sua casa todas as quartas ou quintas-feiras" (CARRASCO, 2003, p.23) - diz o mestre de música com indisfarçável ironia, após ter afirmado, no início da peça, terem encontrado nele um homem como lhes convinha - que entende pouco de arte, mas que pagava bem. Em um episódio em que o alfaiate vem ao seu encontro para lhe trazer um traje encomendado, mesmo tendo feito um traje formal todo florido, com as flores voltadas para baixo, o alfaiate e seus criados também entram no clima de zombaria para extorquir-lhe dinheiro, ao elogiar sua finura e elegância e ao atribuir-lhe o título de fidalgo.

Somente sua esposa, que se mostra desprovida de qualquer vaidade, com um espírito muito mais prático, e a criada Nicole, agem com sinceridade, tentando fazê-lo perceber que seus trajes e atitudes são ridículos. É a denúncia, o desmascaramento da hipocrisia social em que nobres e artistas alimentam seu prestígio à custa de posturas antiéticas como a falsidade e a exploração das misérias alheias.

E de forma irônica, até Cléonte, o pretendente da filha Lucile e para quem os títulos de nobreza pouco importavam, vê-se obrigado a entrar no clima de zombaria, fazendo se passar por fidalgo para, com a cumplicidade da Senhora Jourdain, de Lucile e da criada Nicole, enganar o ingênuo burguês. As personagens mais práticas se obrigam a entrar na encenação que a atitude do burguês exige, na farsa que ele preparou para si mesmo, farsa da qual ele é, ao mesmo tempo, vítima e culpado.

A hipocrisia social presente na obra também é recorrente na sociedade atual, possibilitando a sintonia do público com o tema da peça. Se o aluno da educação de jovens e adultos tem uma maior experiência de vida, por ser adulto, ele será capaz não apenas de compreender a peça, mas de encontrar, nas personagens, tipificações de figuras ainda presentes na sociedade contemporânea.

No entanto, na estrutura da peça, parece que o dramaturgo nega ou, no mínimo, subestima esta experiência do leitor, ao fazer questão de explicitar, nas descrições de algumas cenas, mais que o aspecto físico do cenário, da ação ou dos figurinos. Muitas vezes, nessas orientações ao leitor, observa-se uma nítida perspectivação das cenas que virão, explicando sutilezas que poderiam ser facilmente observadas pelo espectador, sem a necessidade de verbalização do autor. Se a experiência de vida do público o torna capaz de reconhecer os tipos sociais ali representados, não há justificativa para que o autor se intrometa antecipando ao leitor os seus próprios julgamentos sobre os estados de espírito ou o tom humorístico, irônico, zombador das personagens.

Apesar de tal esforço parecer desnecessário, tal procedimento se repete em vários momentos da peça, tal como no exemplo a seguir:

Entra a senhora Jourdain. Ao contrário do marido, é uma mulher sem pretensões de ser fidalga. Veste-se de maneira adequada e possui um grande senso de realidade, que contrasta com o do marido, em sua tentativa de tornar-se um homem elegante (CARRASCO, 2003, p.41). 
Evidencia-se, em trechos com este, sem dúvida, por parte do dramaturgo, uma tentativa de instrução dos atores sobre os procedimentos e expedientes necessários à encenação da peça, o que é indispensável. No entanto, mais que isso, nota-se que alguns detalhes superam a simples orientação aos atores, passando a completar possíveis vazios do texto que, por sua vez, poderiam ser facilmente preenchidos com o repertório do leitor. Por exemplo, o simulacro da atuação de Cléonte quando finge se passar por um falso fidalgo turco já estava implícito na peça, quando seu criado o convida para tramar uma solução para a negativa do burguês para seu pedido de casamento e, também, quando ele convence Lucille a casar-se com ele e a senhora Jourdain a aceitar o casamento pelo simples gesto de tirar a máscara e mostrar a elas a sua verdadeira face. Por essa razão, essa intromissão do autor, nesses momentos, deve ser lida como mais um pretexto para apresentar a sua própria perspectiva na obra.

Tal postura do narrador (dramaturgo) é extremamente coerente com as características dos produtos da indústria cultural, que, segundo Adorno e Horkheimer (1990), procuram extrair qualquer elemento que possa dificultar a recepção da arte. No entanto, também é preciso considerar que

Molière escreveu no século dezessete onde a distinção entre o popular e o erudito era quase inexistente e a diferença entre a cópia e a criação mais que tênue. Naquela época a comédia francesa ia buscar suas fontes de inspiração sobretudo na comédia italiana; comédia essencialmente romanesca, de peripécias múltiplas, cuja intriga era o único recurso cômico. $\mathrm{O}$ público só lhe pedia um divertimento, uma sequência de surpresas, de situações próprias a desencadear o riso. Esse jogo cômico fazia aparecer uma série de enredos e personagens quase sempre estereotipados: histórias de amor contrariado, criados intrigantes, estrepolias de velho ridículo, etc. Foram assim as primeiras farsas de Molière, como L'étourdi e Le Dépit Amoureux (ALENCAR, 1996, p.4).

Apesar dessa distância histórica, porém, é preciso reconhecer que mesmo a peça original tendo sido lançada num contexto em que a diferença entre o popular e o erudito eram muito tênues, num tempo bem anterior à explosão do capitalismo e ao surgimento da sociedade dominada pela indústria cultural, é possível conceber, na adaptação de Carrasco (2010), um caráter metalinguístico que perpassa toda a obra e é evidenciado, principalmente, através da discussão explícita sobre as características da arte, sobre o que é culto ou elegante em se tratando de arte. Tal discussão coloca em confronto dois universos: de um lado, o universo popular das cantigas populares conhecidas pelo senhor Jourdain, com sua forma jocosa de dançar e de lutar esgrima ou ainda o seu mau gosto para vestir-se; e, de outro lado, as danças e as músicas clássicas dominadas pelos mestres e seus discípulos, ou os conhecimentos eruditos do mestre da filosofia.

Como já era de se imaginar, a cultura popular do protagonista é, muitas vezes na peça, exposta de forma a endossar o preconceito contra a figura do burguês e ao grupo que ele representa, exacerbando sempre o que ele desconhece, o que ele não domina, para provocar o efeito cômico. De forma cômica, porém, como em toda e qualquer discussão que a peça se proponha a fazer, os porta-vozes do universo erudito, por sua vez, também são rebaixados e ridicularizados por meio da revelação de suas hipocrisias, de suas vigarices, de suas posturas pouco éticas e pouco admiráveis frente à inocência do senhor Jourdain e frente ao interesse econômico que suplanta os interesses 
artísticos e culturais. A sobreposição dos interesses econômicos sobre os ideológicos e culturais, portanto, não são apenas exacerbados, na cultura capitalista, uma vez que suas raízes se sustentam num tempo ainda anterior à cultura de massas.

Nessa perspectiva, é interessante destacar, também, a cena em que os mestres contratados pelo senhor Jourdain para ensinar-lhe a moderação, a elegância, a fineza do mundo clássico, começam uma discussão absurda sobre qual arte seria a melhor e acabam chegando às vias de fato, numa briga ridícula, mas muito engraçada. Trata-se de uma disputa de vaidades, na qual cada um tenta convencer o senhor Jourdain e os outros profissionais de que sua arte é a mais importante e a mais utilitária. Discutir a utilidade da arte é uma postura típica do mundo contemporâneo, cujos valores aos bens são atribuídos em função de critérios mercadológicos, de modo que seria difícil que as personagens da peça chegassem a um consenso sobre qual arte seria a melhor e mais útil. De forma irônica, é o senhor Jourdain, o "grosseirão" que é ridicularizado durante toda a peça, que tenta desesperadamente conter as fúrias de seus contratados, tentando impedir, sem sucesso, a explosão da briga.

A abordagem do tema na peça, portanto, não exerce uma função pedagógica no sentido de levar o espectador / leitor a posicionar-se favorável ou contrariamente a qualquer tipo de produção, pois se há uma ridicularização da cultura popular ou da ignorância do senhor Jourdain, também não há uma valorização da cultura erudita, uma vez que na briga entre os representantes das diferentes modalidades artísticas não há vitoriosos, o que é bastante coerente. De fato, se considerarmos este caráter metalinguístico da peça, associado ao seu caráter pedagógico, poderemos inferir que, neste projeto, Walcyr Carrasco consegue propor uma discussão entre as diferentes formas de expressão da arte, sem, contudo, estabelecer ou impor juízo de valor, não buscando, portanto, a adesão de seu leitor a nenhuma categoria específica de arte nem de cultura. Popular e erudito são postos em diálogo para provocar o efeito do humor. Na verdade, a peça como um todo, perpassada pelo humor, pelo riso, contém, sim, uma crítica velada, mas não necessariamente contra uma ou outra forma de arte, mas sim contra os excessos humanos, levando o leitor a perceber quão infundados e sem sentido são os excessos humanos, em todas as esferas da vida social.

\section{Considerações finais}

A partir dessa leitura da peça adaptada de $O$ burguês fidalgo, de Molière, por Walcyr Carrasco, foi possível perceber um explícito projeto de readequação e reendereçamento do texto a um novo público, o público da modalidade de educação de jovens e adultos - EJA, para quem foi idealizada a Coleção Palavra da gente.

Analisando-se os traços estilísticos característicos de cada gênero literário, ficou constatado que, apesar de pertencer ao drama, no seu aspecto substantivo do gênero, a peça também apresenta, em seus traços estilísticos, a exemplo do épico, algum direcionamento e manipulação por parte de um possível locutor, que faria um papel semelhante ao do narrador num texto narrativo, por exemplo. Tal papel se explicita através da tentativa de perspectivação dos fatos apresentados, uma vez que o dramaturgo se vale de uma série de expedientes que lhe garantem certo controle dos percursos do leitor ao longo da peça. Entre tais expedientes, é possível citar o recurso à fala das personagens, que guiam a impressão do leitor sobre as outras personagens, evitando que as personagens se apresentem por si só, de forma objetiva na peça e, 
também, as intromissões explícitas do dramaturgo nas orientações ao leitor ou ao artista, ao longo do texto.

Mais do que simplesmente explicar como cada cena foi idealizada, muitas vezes, o dramaturgo utiliza este espaço para orientar a recepção da cena, a interpretação, o posicionamento ideológico. Tal procedimento não só é verdadeiro, como foi assumido por Walcyr Carrasco, ao final do livro, quando ele afirma que, apesar de o texto original não apresentar indicações das atitudes dos personagens, bem como de suas reações, sua intenção foi facilitar a compreensão do texto adequando-o "para quem não está tão familiarizado com textos teatrais, orientando algumas reações e mudanças de estado de espírito, assim como indicando atitudes, gestos e passagens que estavam implícitos no original" (CARRASCO, 2003, p.94).

Consideramos, no entanto, tal procedimento desnecessário, quando assumido em demasia, uma vez que, apesar de o público implícito não ter um repertório de leituras anteriores, ele possui um amplo horizonte de expectativas - para usar a terminologia da estética recepcional - que lhe garante a autonomia necessária para compreender a peça de maneira fluente. Assim, os vazios, os implícitos do texto original, seriam importantíssimos para a garantia da formação desse leitor. Afinal, o texto já apresenta uma linguagem simples, prosaica, versátil e bastante acessível para diferentes públicos. Além do mais, como a coleção não é direcionada a qualquer adulto, mas ao adulto estudante da EJA, espera-se que este leitor poderá contar com o apoio do professor para ajudá-lo na leitura crítica dos textos e da vida. A falta de vazios a serem preenchidos delimitam e atenuam as possibilidades de participação do leitor na construção de sentidos para o texto, por meio da ativação de seu repertório cultural. Desse modo, a vasta experiência de vida desses neoleitores para quem a peça se destina é desconsiderada.

É preciso enfatizar, também, que a preocupação com a elaboração e financiamento de materiais de leitura para esse novo público de leitores em formação os neoleitores - apesar de ainda pouco expressiva em número de publicações, é uma iniciativa de elevada importância e deve ser valorizada e estimulada no Brasil, principalmente quando se trata de materiais de leitura literária, tradicionalmente negligenciada ou mal abordada na história da educação brasileira.

\section{Referências}

ADORNO, T.; HORKHEIMER, M.. -O Iluminismo como mistificação das massasll. In: COSTA LIMA, L. Teoria da cultura de massa. Rio de Janeiro: Paz e Terra, 1990.

ALENCAR, J. A.. O burguês ridículo: Introdução. In: MOLIÈRE. O burguês ridículo. Trad. José Almino. Adapt. Guel Arraes e João Falcão. Rio de Janeiro: Sette Letras, $1996 . \quad$ Disponível em: <http://www.casaruibarbosa.gov.br/dados/DOC/artigos/aj/FCRB_JoseAlminoAlencar Burgues_ridiculo.pdf $>$ Acesso em: set. 2014.

ARRIGUCCI JR., D. Teoria da narrativa: posições do narrador. In: Jornal da Psicanálise. São Paulo: SBPC, vol. 31, nº 57, 1998. 
BRASIL. Ministério da Educação. Secretaria de Educação Fundamental. Proposta Curricular para a educação de jovens e adultos: segundo segmento do ensino fundamental: $5^{\mathrm{a}}$ a $8^{\mathrm{a}}$ série: introdução / Secretaria de Educação Fundamental, 2002.

CADEMARTORI, L.. O professor e a literatura para pequenos, médios e grandes. Belo Horizonte: Autêntica editora., 2009 - (Série Conversas com o Professor ; 1).

CANDIDO, A.. Formação da literatura brasileira: momentos decisivos 1750-1880. 15 ed. Rio de Janeiro: Ouro sobre Azul, 2014.

CARRASCO, W.. O burguês fidalgo / Molière; Tradução e adaptação, organização e apresentação Marisa Lajolo. - 1. Ed. - São Paulo: Moderna, 2003 (Coleção Palavra da gente; V. 5. Peça teatral).

COELHO, N. N.. Panorama histórico da literatura infantil/juvenil. $5^{\mathrm{a}}$ ed. Amarilys, 2010 .

COMPAGNON, A. O demônio da teoria - Literatura e senso comum. Trad. Cleonice Paes Barreto Mourão, Consuelo Fortes Santiago - Belo Horizonte: Ed. UFMG, 2001 (Humanitas).

CORRÊA, Suani Trindade. De O avarento de Moliére, a mão de vaca dos palhaços trovadores: o texto teatral em processo. Dissertação de Mestrado (Letras). Universidade Federal do Pará. Belém, 2011.

ECO, U.. Seis passeios pelos bosques da ficção. São Paulo: Companhia das Letras, 1994.

FLORY, A. V.. Literatura e teatro: encontros e desencontros formais e históricos. In: Revista JIOP, No 1, Departamento de Letras, 2010.

FORMIGA, G. M.. Adaptação de clássicos literários: uma história de leitura no Brasil. João Pessoa, 2009. 262 f. Tese (Doutorado em Letras) - Universidade Federal da Paraíba.

GERALDI, J. W. (Org.). O texto na sala de aula. 4. ed. São Paulo: Ática, 2008.

PAIVA, J.. Neoleitor. In: FRADE, I. C. A. da S.; COSTA VAL, M. da G.; BREGUNCI, M. das G. de C.. (Orgs). Glossário CEALE: Termos de alfabetização, leitura e escrita para educadores. Belo Horizonte: UFMG / Faculdade de Educação, 2014. Disponível em: www.ceale.fae.ufmg.br/app/webroot/glossarioceale/. Acesso: Mai / 2018.

ISER, W.. O ato da leitura - uma teoria do efeito estético, v. 1, São Paulo: Editora 34, 1996.

LAJOLO, M.. Apresentação: Uma comédia de ontem, de hoje, de sempre. In: CARRASCO, Walcyr. O burguês fidalgo / Molière; Tradução e adaptação, organização e apresentação Marisa Lajolo. - 1. Ed. - São Paulo: Moderna, 2003 (Coleção Palavra da gente; V. 5. Peça teatral). 
Entrevista a Iracema Nascimento. A leitura como moeda de trânsito social. In: VÓVIO, Cláudia Lemos; MOURA, Mayra; RIBEIRO, Vera Masagão e SANTANA, Wagner. Políticas e práticas de leitura no Brasil. São Paulo: Ação Educativa, 2003. (Série Em Questão, no 2).

LIMA, E. A. P.; EITERER, C. L.. Acervo literário destinado ao público da EJA: Coleções Palavra da Gente, É só o Começo e Literatura para Todos. Disponível em: http://www.catedraunescoeja.org/GT07/COM/COM005.pdf. Acesso em: set. 2014.

ROSENFELD, A.. O teatro épico. São Paulo, Perspectiva, 1985.

TIEPOLO, E. V.. Neoleitores no Brasil Alfabetizado. Disponível em: http://portal.mec.gov.br/index.php?option=com_docman\&task=doc_download\&gid=75 $1 \&$ Itemid=. Acesso em 05 out. 2014.

Uma política de leitura para todos: leitores e neoleitores. In: MACHADO, Maria Margarida. Em Aberto, Brasília, v. 22, n. 82, p. 121-133, nov. 2009.

TIUMAN, Patrícia Elisabel Bento. Produção literária infantil e juvenil de Walcyr Carrasco: uma análise da construção narrativa e da representação de grupos sociais (1979 - 2010). 140 f. Dissertação (Mestrado em Letras) - Universidade Estadual de Maringá. Maringá, 2011. 